\title{
HIV Specific Humoral Immune Response in Rio de Janeiro, Brazil
}

\section{Bongertz ${ }^{+}$, CI Costa, ML Guimarães, MFG Soares-da-Costa, B Grinsztejn*, The HEC/Fiocruz AIDS Clinical Research Group*/++, FI Bastos**, JH Pilotto***, EC João Filho****, R Loureiro*****, P Chequer******, PR Telles $* * * * * * *$, B Galvão-Castro $* * * * * * *$, MG Morgado}

\begin{abstract}
Laboratório de AIDS e Imunologia Molecular, Departamento de Imunologia, *Hospital Evandro Chagas, Instituto Oswaldo Cruz, Av. Brasil 4365, 21045-900 Rio de Janeiro, RJ, Brasil **Centro de Informações em Ciência e Tecnologia, Fiocruz, RJ ***Hospital Geral de Nova Iguaçu, RJ **** Hospital dos Servidores do Estado, RJ *****Secretaria da Saúde e Meio Ambiente, Porto Alegre, RS ******Programa Nacional DST/ AIDS, MS, Brasília, DF *******NEPAD, Universidade Estadual do Rio de Janeiro ********Laboratório Avançado de Saúde Pública, Centro de Pesquisas Gonçalo Moniz, Fiocruz, Salvador, BA, Brasil
\end{abstract}

Efforts to characterize HIV-1 polymorphism and anti-HIV immune response are being made in areas where anti-HIV/AIDS vaccines are to be employed. Anti-HIV-1 humoral immune response is being studied in infected individuals resident in Rio de Janeiro, in distinct cohorts involving recent seroconvertors, pregnant women or intravenous drug users (IDU). Comparative analyses of specificity of antibody response towards epitopes important for anti-HIV-1 immune response indicate quantitative differences between cohorts, with an exceptionally strong response in IDUs and weakest response in pregnant women. However, a comparative analysis between pregnant women cohorts from Rio de Janeiro and Rio Grande do Sul indicated an even lower response (with exception of the anti-V3-C clade peptide recognition) for the southern cohort. Studies analysing the immune function of the humoral response indicate a quite elevated occurrence of antibodies capable of neutralizing heterologous primary HIV-I isolates from Rio de Janeiro. Attempts to correlate seroreactivity with HIV-1 neutralization with respect to HIV-1 polymorphism were not very successfull: while the Brazilian B clade B" variant could be recognized by binding assays, no significant distinction of HIV-1 clades/variants was observed in viral neutralization assays.

Key words: HIV-1 - antibody specificity - neutralization - genotypes

Attempts to develop anti-HIV/AIDS vaccines have been checked by the great genetic variability of HIV-1 (Bloom 1996). Genotyping studies have subdivided HIV-1 into several subtypes, while serotyping analyses have not lead to a definition of distinct HIV-1 serotypes (Moore \& Trkola 1997). A clustering of "serospecificities" based on binding of antibodies to synthetic peptides corresponding to genotypic subtypes indicate a partial correspondence between genotype and serotype

\footnotetext{
This work was supported by PIAF/Fiocruz, MS, CNPq 529022/95-6 and UNDP/World Bank 063/94

${ }^{+}$Corresponding author. Fax: +55-21-280.1486. E-mail: bongertz@gene.dbbm.fiocruz.br

${ }^{++}$The HEC/Fiocruz AIDS Clinical Research Group: VGV Santos, VC Rolla, S Cavalcante, MCG Galhardo, MRC Guimarães, R Khalili, R Valles de Souza Received 11 March 1998 Accepted 16 April 1998
}

(Moore et al. 1996, Simon et al. 1996). However, analyses of the functional HIV neutralizing humoral response has not indicated a correlation with HIV-1 genotypes (Weber et al. 1996) but a "grouping" of sera with similar neutralization potency and cross-clade activity (Trkola et al. 1995, Kostrikis et al. 1996, Nyambi et al. 1996). The need for an anti-AIDS vaccine concomitant to HIV-1 variability motivates studies of viral polymorphism in the different geographic regions with high prevalence of HIV infection, in parallel to studies on specific human immune response to the various clades in the different areas. Identification of specific immune reactivities (Fenyö et al. 1996) and analyses of its potential protectivity against development of immune deficiency in HIV infection is needed for development and evaluation of effective vaccine candidates.

This report presents results of several studies of humoral immune response against HIV-1 in Rio de Janeiro, Brazil, in different patient cohorts to allow comparative evaluations. 


\section{MATERIALS AND METHODS}

Patients - Data is presented from different patient groups: (a) Vertical HIV transmission group (TV-RJ), accompanied at the Hospital Evandro Chagas, Instituto Oswaldo Cruz, RJ; the Hospital Geral de Nova Iguaçu, RJ and the Hospital dos Servidores do Estado, RJ, comprised of 125 HIV1 infected pregnant women and women that had given birth recently; (b) 30 individuals from an injecting drug user (IDU) cross-sectional study, comprised of a mostly male group $(97 \%)$, of the "Projeto Brasil", Centro de Informações em Ciência e Tecnologia, Fiocruz, RJ, and NEPAD, Universidade Estadual do Rio de Janeiro; (c) 85 asymptomatic HIV-1 infected individuals resident in Rio de Janeiro (RN-RJ), Hospital Evandro Chagas; (d) a cohort of 51 pregnant asymptomatic HIV-1 infected women resident in Rio Grande do Sul (TV-RS), accompanied by the Secretaria da Saúde e Meio Ambiente, Porto Alegre, RS.

Seroreactivity - Duplicates of sequentially diluted heat inactivated plasma were incubated with different biotinylated synthetic peptides bound to multiwell plates precoated with streptavidin. Specific reactivity was assessed (including $8 \mathrm{M}$ urea washes) by peroxidase-conjugated anti-human- $\operatorname{IgG}$ binding and $\mathrm{H}_{2} \mathrm{O}_{2}$ /TMB revelation (Bastos et al. 1997). Reactivity was assessed as dilution titer reaching at least twice the mean binding of the two control plasma included in each assay plate. The variation of total numbers of plasma analyzed derives from exclusion of data from doubtful analyses.

Neutralization assay - Supernatants from primary co-cultures collected between the 7 th and 21 st day of co-culture were used as viral stocks. The standard assay employing pre-incubation of viral dilutions with heat inactivated plasma followed by addition of phytohemagglutinin-activated normal human PBMC (Albert et al. 1990, Bongertz et al. 1997). Changes of at least $90 \%$ of the medium after 24 and $48 \mathrm{hr}$ were carried out in order to eliminate eventually present anti-p24 antibodies in the plasma used (Albert et al. 1993). Evaluation of neutralization was carried out by measurement of the HIV-1 p24 antigen (DuPont HIV-1 antigen assay) in the culture supernatants on day 7. Neutralization was considered positive when a reduction of at least $75 \%$ of viral input was detected as measured by $\mathrm{p} 24$ concentration (Bongertz et al. 1997).

Heteroduplex mobility assay (HMA) - The test was carried out according to Delwart et al. (1993) using the reagents indicated. Differentiation between B subtype and the B" variant of subtype B was carried out using analysis of Fok 1 restriction enzyme fragments by agarose gel electrophoresis (Morgado et al. 1996).
Statistical analyses - Fisher's exact test was used for statistical evaluation (significance defined as $\mathrm{p}<0.05)$.

\section{RESULTS}

\section{SEROREACTIVITY}

Seroreactivity of plasma from the IDU cohort Analyses of basic social-demographic and clinical data showed that the three groups here assessed: IDUs, homo and bisexual males (sexual transmission - males, RN cohort), and females infected through sexual intercourse (sexual transmission females, TV-RJ cohort) have comparable distribution along age ranges and clinical staging, although the TV cohort included $46 \%$ of pregnant women at plasma collection.

Higher reactivity against all peptides tested was observed for the IDU vis-à-vis sexually infected plasma, both considering whole groups (Table I) and matching by clinical stages, with differences in peptide recognition more expressive in more advanced clinical stages (data not shown). Reactivity with epitopes important for HIV-1 neutralization outside of the V3-loop (V2, gp41 735-752) was especially high in IDU plasma (Table II).

Seroreactivity of vertical transmission cohorts - In consideration to the size of Brazil (8.511.965 $\mathrm{km}^{2}$ ) and regional HIV-1 polymorphism described earlier (Galvão-Castro et al. 1996), a comparative analysis between vertical HIV-1 transmission cohorts from Rio de Janeiro (RJ, southeast region) and Rio Grande do Sul (RS, south region) was carried out. Unfortunately, little clinical data from the TV-RS cohort was available, but all women were pregnant, with HIV-1 positive sorological diagnosis with no clinical indication of infection (asymptomatic). The TV-RJ cohort included 43\% of symptomatic women. Comparing reactivities of plasma from Rio Grande do Sul with plasma from different cohorts from Rio de Janeiro, lower reactivity was generally observed for TV-RS. Comparing reactivities with a vertical transmission cohort from Rio de Janeiro, reactivity towards V3-B

TABLE I

Amino-acid sequence of the synthetic peptides used

\begin{tabular}{ll}
\hline Peptide & Sequence \\
\hline ID & GFWGCSGLICTVPWNAS \\
V2-MN & IRDKMQKEYALLYKL \\
V2-BR & VDKEKKEYALFYNL \\
$735-752$ & DRPEGIEEEGEKDRDRS \\
V3-B & NTRKSIHIGPGRAFY \\
V3-B” & NTRKSIHMGWGRAFY \\
V3-C & KSIRIGPGQTFYAT \\
V3-FBR & NTRKSIPLGPGRAFY \\
V3-F & RKSIHLGPGQAFYTT \\
V3-D & RQRTIHIGPGQALYTT \\
\hline
\end{tabular}


TABLE II

Reactivity of plasma from HIV-1 infected individuals belonging to different cohorts is expressed in number of reactive sera per total number tested. Fisher's exact test was used for comparison of reactivities of plasma from the IDU ${ }^{a}$ cohort versus the other cohorts included

\begin{tabular}{llclrl}
\hline Peptide & Blood (IDU) & Sexual $\left(\right.$ Male, $\left.\mathrm{RN}^{b}\right)$ & $\mathrm{p}$ & Sexual (female, $\left.\mathrm{TV}^{c}\right)$ & $\mathrm{p}$ \\
\hline ID & $22 / 25(88 \%)$ & $29 / 34(56 \%)$ & 1.0 & $24 / 31(77 \%)$ & 0.5 \\
V2-MN & $20 / 25(80 \%)$ & $10 / 32(31 \%)$ & 0.0004 & $1 / 31(3 \%)$ & 0.0000 \\
V2-BR & $19 / 24(79 \%)$ & ND & & $8 / 36(23 \%)$ & 0.0000 \\
$735-752$ & $20 / 25(80 \%)$ & $3 / 34(9 \%)$ & 0.0000 & $2 / 32(6 \%)$ & 0.0000 \\
V3-B & $25 / 30(83 \%)$ & $16 / 28(57 \%)$ & 0.02 & $44 / 74(59 \%)$ & 0.02 \\
V3-B” & $22 / 30(73 \%)$ & $20 / 32(63 \%)$ & 0.4 & $56 / 86(65 \%)$ & 0.4 \\
V3-C & $17 / 27(63 \%)$ & $11 / 31(36 \%)$ & 0.04 & $44 / 76(59 \%)$ & 0.6 \\
V3-FBR & $22 / 29(76 \%)$ & $12 / 32(38 \%)$ & 0.003 & $24 / 75(32 \%)$ & 0.0001 \\
\hline
\end{tabular}

$a$ : intravenous drug users; $b$ : asymptomatic patient cohort; $c$ : asymptomatic pregnant women cohort.

was still significantly lower for the southern plasma, as was also detected after correction regarding clinical staging. Interestingly, reactivity with the V3-C peptide was similar for plasma from individuals resident in either region, irrespective of corrections according to clinical data (Table III).

Seroreactivity versus genotype - Attempts to correlate seroreactivity and genotype were undertaken to evaluate the utility of serotyping Brazilian HIV-1. As the HIV-1 subtypes circulating in Brazil up to now (July 1997) have been identified as clades B (including variant B"), F and C, seroreactivity against "consensus" peptides of these clades/variants was assayed.

The results indicate that $73 \%$ of the sera from individuals infected with the B" variant of the B subtype could be identified by serological reactivity (plasma with either exclusive or stronger reactivity against the homologous genotype peptide), while $5.4 \%$ of the sera would be wrongly typed (exclusive or stronger reactivity with heterologous genotype peptides) based on peptide recognition data (Fig. 1). However, sera from individuals infected with the classical B subtype or the F subtype showed no specific recognition of the corresponding V3 peptides, and percentages of plasma with a higher reactivity against a peptide represen- tative of another clade/variant ("wrongly typed") was very high (57\% of sera from individuals infected with the classical B clade HIV-1). The percentage of plasma with no possibility of serotyping (no reactivity or with similar reactivity with the peptides) was highest for plasma from individuals infected with clade F HIV-1 (Table IV).

\section{NEUTRALIZATION}

Heterologous neutralization - Susceptibility assays were carried out with 18 primary HIV-1 isolates derived from patients of the TV-RJ cohort, indicating a higher susceptibility to neutralizing antibodies of the Brazilian primary isolates than described in the literature (Montefiori et al. 1991, Arendrup et al. 1993, Bjoerling et al. 1993, Pilgrim et al. 1997); when plasma diluted to 1:10 were employed, 169 of 223 tests $(76 \%)$ resulted in a neutralization greater than $75 \%$; using 1:50 diluted plasma, 73 of 88 combinations showed neutralization efficacy greater than $75 \%$. Only 2 of the 18 isolates tested showed very low susceptibility to heterologous neutralization (Bongertz et al. 1997). A representative chequer-board neutralization assay comparing susceptibilities of two primary HIV1 isolates and the reference HIV-1 MN strain is shown in Table V.

\section{TABLE III}

Reactivity of plasma from HIV-1 infected individuals resident in two different geographical areas of Brazil is expressed in number of reactive sera per total number tested. Fisher's exact test was used for comparison of reactivities of plasma from the southern (TV-RS) cohort versus the other cohorts included

\begin{tabular}{lcclclcl}
\hline Peptides & TV-RS $^{a}$ & TV - RJ & p & TV-RJ asympt & p & Rio de Janeiro & p \\
\hline V3-B & $16 / 51(31 \%)$ & $53 / 76(70 \%)$ & 0.000 & $17 / 29(59 \%)$ & 0.0204 & $117 / 185(63 \%)$ & 0.000 \\
V3-B” & $11 / 51(22 \%)$ & $54 / 76(71 \%)$ & 0.000 & $22 / 27(74 \%)$ & 0.0000 & $123 / 184(67 \%)$ & 0.000 \\
V3-FBR & $11 / 51(22 \%)$ & $23 / 66(35 \%)$ & 0.15 & $6 / 18(33 \%)$ & 0.35 & $72 / 174(41 \%)$ & 0.013 \\
V3-C & $23 / 51(45 \%)$ & $41 / 64(64 \%)$ & 0.058 & $13 / 20(65 \%)$ & 0.18 & $90 / 171(53 \%)$ & 0.42 \\
\hline
\end{tabular}

$a$ : asymptomatic pregnant women cohort from the south of Brazil; $b$ : asymptomatic pregnant women cohort from Rio de Janeiro; asympt: asymptomatic individuals. 


\section{TABLE IV}

Reactivity of plasma from HIV-1 infected individuals grouped according to genotype/variant with synthetic peptides with corresponding V3-loop amino acid sequences is expressed in number of reactive sera per total number tested (non-reactive sera not indicated)

\begin{tabular}{lccc}
\hline Recognition of peptides & $\begin{array}{c}\text { clade B plasma } \\
\text { vs V3-B peptide }\end{array}$ & $\begin{array}{c}\text { Variant B" plasma } \\
\text { vs V3-B" peptide }\end{array}$ & $\begin{array}{c}\text { Clade F plasma } \\
\text { clade F peptide }\end{array}$ \\
\hline Exclusive & $2 / 51(3.9 \%)$ & $14 / 37(37.8 \%)$ & $0 / 13(0 \%)$ \\
Highest & $4 / 51(7.8 \%)$ & $13 / 37(35.1 \%)$ & $3 / 13(23.1 \%)$ \\
"Typed" & $6 / 51(11.8 \%)$ & $27 / 37(73.0 \%)$ & $3 / 13(23.1 \%)$ \\
No typing possible & $14 / 51(27.4 \%)$ & $5 / 37(13.5 \%)$ & $7 / 13(53.8 \%)$ \\
"Wrongly typed" & $29 / 51(56.9 \%)$ & $2 / 37(5.4 \%)$ & $3 / 13(23.1 \%)$ \\
\hline
\end{tabular}

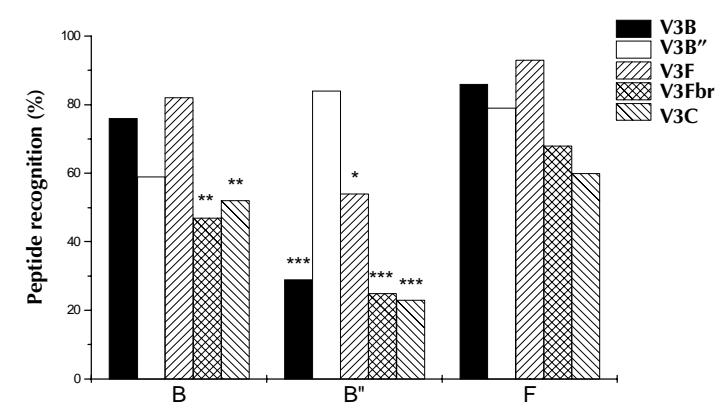

Fig. 1: binding to synthetic V3 loop peptides corresponding to different HIV-1 clades or variants of antibodies in plasma from individuals infected with clade B, variantB" of cade B or clade F HIV-1. Asterisks indicate statistically significant differences between homologous and heterologous reactivities: $*=p<0.05$, $* *=\mathrm{p}<0.01, * * *=\mathrm{p}<0.001$.

Neutralization versus genotype - Crossed neutralization was assayed for 42 clade B HIV-1 isolates, 20 B" variants of $\mathrm{B}$ clade HIV-1 and $2 \mathrm{~F}$ clade isolates, against plasma from individiduals infected with clade B $(n=42)$, variant B' $(n=24)$ or clade $F(n=9)$. Fig. 2 presents an overview of the results obtained.

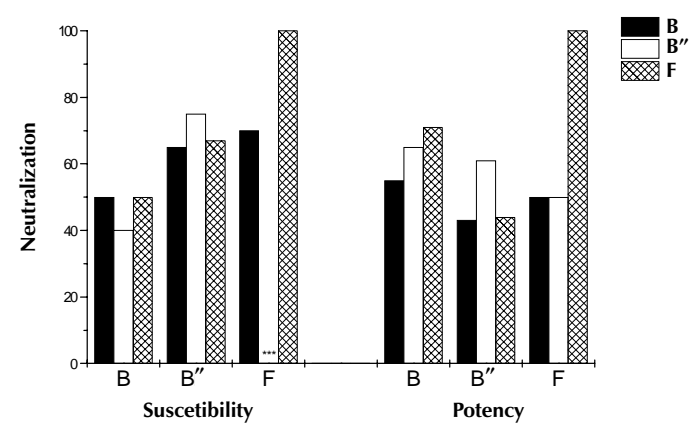

Fig. 2: susceptibility of primary HIV-1 isolates to neutralization by plasma from individuals infected with clade $B$, variant B" of clade B or clade F HIV-1 and potency of plasma from HIV-1 infected individuals against genotyped primary HIV-1 isolates. Asterisks indicate statistically significant differences between homologous and heterologous reactivities: $* * *=$ $\mathrm{p}<0.001$. Absence of asteriks indicate that no statistically significant difference could be observed $(\mathrm{p}>0.05)$.

\section{DISCUSSION}

Reactivity of plasma from HIV-1 infected individuals with synthetic peptides corresponding to classical B subtype HIV-1 isolates referred to in vaccine candidate development has indicated a higher reactivity in North America/Europe in comparison to other geographic areas (Carrow et al. 1991, Bongertz et al. 1994, Pau et al. 1994). More recent data show that, although the $B$ subtype of HIV-1 is predominant in Brazil (Potts et al. 1993), as described for North America and Europe, the typical GPGR amino acid sequence at the top of the gp120 envelope V3 loop is substituted by GWGR in a significant number of Brazilian HIV-1 subtype B isolates (Morgado et al. 1994), now being designated B" variant of the classical B genotype. Other HIV-1 clades and recombinations of clades have been detected in Brazil by different research groups (as reviewed in Galvão-Castro et al. 1996). Regional predominance of HIV-1 subtypes has been indicated and more recently confirmed by Hendry et al. (1996) and several studies presented at the 2nd Brazilian Symposium on Basic Research in HIV/AIDS in 1997.

One of the groups at risk for HIV-1 infection which presents continuously increasing incidence of infection is the IDUs. This group has a characteristically higher co-infection with organisms not generally associated with HIV infection, in addition to "traditional" opportunistic infections (Manoff et al. 1996), while presenting a comparable median survival time after AIDS diagnosis to that observed in other exposure categories. However, these individuals may not be representative of the general population of IDUs, but should be assessed as "survivors" of HIV infection, considering the higher mortality of HIV infected IDUs not diagnosed as AIDS (Stoneburner et al. 1988) or IDUs in general, due to a variety of non-HIVrelated causes, e.g. drug overdoses (Des Jarlais et al. 1988) or viral hepatitis. The higher reactivity of IDU plasma with immunologically important $e n v$ epitopes, in comparison to sexually infected males, may indicate a more extensive (possibly 
TABLE V

Neutralization of primary HIV-1 isolates TV31 and TV68 and of the reference HIV-1 isolate HIV-1 MN by plasma from HIV-1 infected women

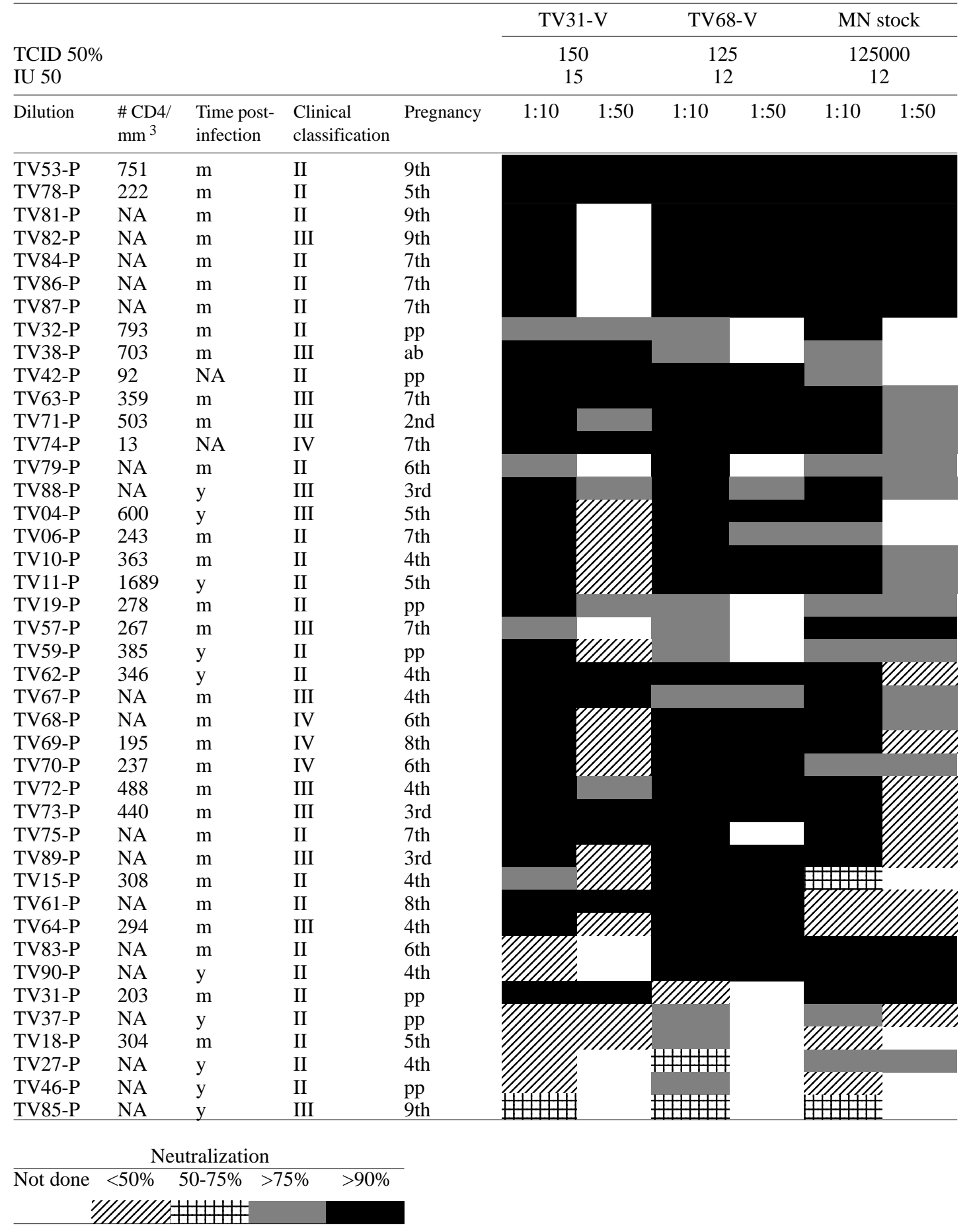

\#CD4/mm $3 \mathrm{~m}^{3}$ : number of CD4 positive lymphocytes per $\mathrm{mm}^{3}$ of blood at sample collection; time post-infection: time in months $(\mathrm{m})$ or years (y) between first positive HIV-1 serology and sample collection; clinical classification according to CDC (1986); pregnancy information at sample collection: month of pregnancy; ab: spontaneous abortion; pp: post partum; NA: not available. 
more effective? earlier? longer duration?) immune response in these HIV-1 infected IDUs. Such a conclusion would be compatible to the similar clinical progression observed after AIDS diagnosis among patients from Rio de Janeiro between transmission groups (Gadelha 1997) despite higher prevalence of co-infections and higher levels of other diagnosis related to unhygienic injection practices and physical neglect (Haastrecht et al. 1996).

Only one study comparing plasma from different regions of Brazil was carried out, including corrections for clinical data of the different cohorts. It has been known that reactivity with the consensus V3-B peptide is lower in Brazil than described for North America or Europe (Carrow et al. 1991, Cheingsong-Popov et al. 1992, Bongertz et al. 1994). Recognition of V3-B peptides (including V3-B") was even lower in the southern than in the southeastern region, while recognition of the V3$\mathrm{C}$ consensus peptide was at similar levels, confirming indications of a higher prevalence of $\mathrm{C}$ subtype HIV-1 in the south of Brazil. Recognition of the V3-FBR peptide, although lower for southern plasma, was not significantly lower observed with Rio de Janeiro plasma, when correction for clinical data was included. The lower reactivity observed in the TV cohort reflects the lower overall immune response normally observed in pregnant women (Mikyas et al. 1997), but appears to be a characteristic of the southern region, as it was evident even in comparison with a clinically matched cohort from Rio de Janeiro, indicating that there is a shift in HIV-1 subtype distribution in Brazil. Such a shift could be significant for vaccine trials: if the data presented here is confirmed for other HIV-1 infected groups with different exposure risks, considerations valid for African vaccine trials (where the $\mathrm{C}$ subtype is the most prevalent, according to UNAIDS, Geneva, Switzerland) will have to be applied, at least for the south of Brazil.

Correlation between genotype and serotype in HIV-1 infection has not been established as yet. While serotyping of Thailandese sera of individuals infected with genotypes B or E is possible (Wasi et al. 1995) with some exceptions (Louisirirotchanakul et al. 1997), no such correlation between genotype and serotype could be established between infections with other HIV-1 clades (Moore $\&$ Trkola 1997). In the present study, analysis of serotype and genotype indicates that no important differences between clade $\mathrm{B}$ and $\mathrm{F}$ peptides could be observed testing plasma from clade $\mathrm{B}$ or clade $\mathrm{F}$ infected individuals. Cross-reactivity was also high in respect to the $\mathrm{C}$ peptide. However, an identification of the variant B" HIV-1 infection may be possible: only 2 of 37 plasma showed preferential recognition of non B" peptides.
As no valid correlation between seroreactivity and HIV-1 neutralization has been established (Nyambi et al. 1997), in vitro assays are needed to identify effective antibody activity. Neutralization susceptibility of primary HIV-1 isolates has been described as being quite low (Lathey et al. 1997). In the present study extensive cross-neutralization has been shown to exist between HIV-1 isolates from HIV-1 infected women and heterologous plasma from the same cohort. A chequer-board neutralization comparing two primary HIV-1 isolates with similar tissue culture infectivity and the reference HIV-1 isolate MN (similar infectious doses used) indicates extensive cross-neutralization: of 42 plasma tested, 31 were able to neutralize all 3 isolates (and 7/17 tested using both 1:10 and 1:50 diluted plasma). The cross-neutralization effect could not be correlated to the HIV-1 genotype, and could be shown to be more extensive than the cross-recognition of clade specific V3-loop peptides. This extensive cross-neutralization observed between HIV-1 subtypes prevalent in Rio de Janeiro, including the B" variant of clade B, indicates the importance of epitopes outside of the V3-loop for the induction of neutralizing antibodies. Although two other epitopes known to be important for the induction of neutralizing antibodies (V2-loop peptides and the gp41 735-752 peptide, Cheingsong-Popov et al. 1992) have been employed in the seroreactivity assays, no important recognition of these epitopes could be observed in plasma with high neutralization potency.

The data shown indicate that the heterogeneity of HIV-1 infection is very high in Brazil, as described elsewhere: not only differences between cohorts defined by distinct exposure categories but also between individuals from distinct geographical regions. However, although more studies have to be carried out before final conclusions can be drawn, these differences in seroreactivity and genotype may not be of significant biological relevance, as indicated by the neutralization susceptibility/ potency studies which do not distinguish HIV-1 subtypes/variants circulating in Rio de Janeiro, Brazil.

\section{REFERENCES}

Albert J, Abrahamson B, Nagy K, Aurelius E, Gaines H, Nystrom G, Fenyoe EM 1990. Rapid development of isolate-specific neutralizing antibodies after primary HIV-1 infection and consequent emergence of virus variants which resist neutralization by autologous sera. AIDS 4: 107-112.

Albert J, Bjoerling E, Von Gegerfelt A, Scarlatti G, Thorstensson R, Zhang Y, Fenyoe EM 1993. Antigen detection is a reliable method for evaluating HIV/ SIV neutralization assays. AIDS Res Hum Retroviruses 9: 501-504. 
Arendrup M, Sönnerborg A, Svennerholm B, Akerblom L, Nielsen C, Clausen H, Olofsson S, Nielsen JO, Hansen JES 1993. Neutralizing antibody response during human immunodeficiency virus type 1 infection: type and group specificity and viral escape. $J$ Gen Virol 74: 855-863.

Bastos FI, Soares-da-Costa MFG, Telles PR, Morgado MG, Bongertz V 1997. Higher seroreactivity with env epitopes in HIV-1 infected IDUs. p.11. Segundo Simpósio Brasileiro de Pesquisa Básica em HIV/ AIDS, Angra dos Reis, RJ.

Björling E, Scarlatti G, Von Gegerfelt A, Albert J, Biberfeld G, Chiodi F, Norrby E, Fenyö EM 1993. Autologous neutralizing antibodies prevail in HIV2 but not in HIV-1 infection. Virology 193: 528-530.

Bloom BR 1996. A perspective on AIDS vaccines. Science 272: 1888-1889.

Bongertz V, Costa CI, Santos VGV, The HEC/Fiocruz AIDS Clinical Research Group, João Filho EC, Galvão-Castro B, Morgado M 1997. Correlation between Susceptibility of primary HIV-1 isolates to autologous and heterologous neutralizing antibodies. AIDS 11: 977-986.

Bongertz V, Jansson M, Flodby P, Morgado MG, GalvãoCastro B, Wigzell H 1994. Analysis of antibody specificity against the third variable region of the envelope gp120 of HIV-1 in plasma from HIV-1 positive individuals resident in Brazil. Braz J Med Biol Res 27: 1225-1236.

Carrow EW, Vujcic LK, Glass WL, Seamon KB, Rastogi SC, Hendry RM, Boulos R, Nzila N, Quinnan Jr GV 1991. High prevalence of antibodies to the gp120 $\mathrm{V} 3$ region principal neutralizing determinant of HIV$1 \mathrm{MN}$ in sera from Africa and the Americas. AIDS Res Hum Retroviruses 7: 831-838.

CDC - Centers for Disease Control 1986. Classification system for human T-lymphotropic virus type III/ lymphoadenopathy associated virus infections. Ann Int Med 105: 234-237.

Cheingsong-Popov R, Callow D, Beddows S, Shaunak S, Wasi C, Kaleebu P, Gilks C, Petrascu IV, Garaev WM, Watts DM, Constantine NT, Weber JN 1992. Geographic diversity of HIV-1: serologic reactivity to env epitopes and relashionship to neutralization. J Inf Dis 165: 256-261.

Delwart EL, Shpaer EG, Louwagie J, Mc Cutchan FE, Grez M, Ruebsamen-Waigmann H, Mullins J 1993. Genetic relationships determined by a DNA heteroduplex motility assay: Analysis of HIV-1 env genes. Science 262: 1257-1261.

Des Jarlais DC, Castriel C, Friedman SR 1988. The new death among IV drug users, p. 256-281. In IB Corless, M Pittman-Lindeman (eds), AIDS: Principles, Practices and Politics, Hemisphere Publ Co, New York.

Fenyö EM, Albert J, McKeating J 1996. The role of the humoral immune response in HIV infection. AIDS 10 (Suppl A): S97-S106.

Gadelha AJ 1997. Casos notificados de AIDS no Município do Rio de Janeiro, 1983-1993. Análise de sobrevida, $\mathrm{PhD}$ Thesis, Universidade de São Paulo, SP, 152 pp.
Galvão-Castro B, Couto-Fernandez JC, Mello MA, Linhares de Carvalho MI, Castello Branco LR, Bongertz V, Ferreira PC, Morgado MG, Tanure A, Sabino E, The Brazilian Network for HIV-1 Isolation and Characterization 1996. A Nationwide effort to systematically monitor HIV-1 diversity in Brazil: Preliminary results. Mem Inst Oswaldo Cruz. 91: 335-338.

Haastrecht HJA van, Bindels PJ, Sluijs TA 1996. The impact of drug users on inpatient hospital care during HIV epidemic in Amsterdam. Int J Epidemiol 4: 846-853.

Hendry RM, Hanson CV, Bongertz V, Morgado MG, Duarte A, Casseb J, Brigido L, Sabino E, Diaz R, Galvão-Castro B 1996. Immunoreactivity of Brazilian HIV isolates with different V3 motifs. Mem Inst Oswaldo Cruz 91: 347-348.

Kostrikis LG, Michalopoulou ZH, Cao Y, Moore JP, Ho DD 1996. Determining neutralization serotypes of HIV-1 by neural networks. AIDS Res Human Retrov 12: 1667-1669.

Lathey JL, Pratt RD, Spector SA 1997. Appearance of autologous neutralizing antibody correlates with reduction in virus load and phenotype switch during primary infection with HIV-1. J Inf Dis 175: 231233.

Louisirirotchanakul S, Bobkov A, Shaffer N, Mastro TD, Wasi C, Weber J, Cheingsong-Popov R 1997. Sequence analysis of an HIV type 1 env subtype $\mathrm{E}$ isolate from Thailand with discordant V3-loop serotyping. AIDS Res Human Retrov 13: 807-808.

Manoff SB, Vlahov D, Herskowitz A 1996. HIV infection and infective endocarditis among injecting drug users. Epidemiology 7: 566-570.

Montefiori DC, Zhou J, Barnes B, Lake D, Hersch EM, Masuho Y, Lefkowitz JR JB 1991. Homotypic antibody response to fresh clinical isolates of human immunodeficiency virus. Virology 182: 635-43.

Moore J, Trkola A 1997. HIV Type 1 coreceptors, neutralization serotypes, and vaccine development. AIDS Res Human Retrov 13: 733-736.

Moore JP, Cao Y, Leu J, Qin L, Korber B, Ho DD 1996. Inter- and intra-clade neutralization of human immunodeficiency virus type 1: genetic clades do not correspond to neutralization serotypes but partially correspond to gp120 antigenic serotypes. J Virol 70: 427-44.

Morgado MG, Sabino E, Shpear E, Bongertz V, Brigido L, Guimarães MDC, Castilho EA, Galvão-Castro B, Mullins JI, Hendry RM, Mayer A 1994. V3 region polymorphism in HIV-1 from Brazil : Prevalence of subtype B strains divergent from the North American/European prototype and detection of subtype F. AIDS Res Human Retrov 10: 569-575.

Morgado MG, Guimarães ML, Gripp CBG, Costa CI, Santos VGV, Linhares-de-Carvalho MI, Bastos FI, Galvão-Castro B, Bongertz V 1996. HIV-1 diversity in patients from Rio de Janeiro, Brazil. TuA103 XI Intl Conf AIDS, Vancouver, Canada.

Mikyas Y, Aziz N, Harawa N, Gorre M, Neagos N, Nogueira M, Wafer D, Dillon M, Boyer PJ, Bryson YJ, Plaeger S 1997. Immunologic activation during 
pregnancy: serial measurement of lymphocyte phenotype and serum activation markers in HIV-infected and uninfected women. J Reprod Immunol 33: 157170.

Nyambi PN, Willems B, Janssens W, Fransen K, Nkengasong J, Peeters M, Vereecken K, Heyndrickx, Piot P, Van der Groen 1997. The neutralization relationship of HIV-1, HIV type 2, and SIVcpz is reflected in the genetic diversity that distinguishes them. AIDS Res Human Retrov 13: 7-17.

Nyambi PN, Nkengason GJ, Lewi P, Andries K, Janssens W, Fransen K, Heyndricks L, Piot P, Van der Groen G 1996. Multivariate analysis of human immunodeficiency virus Type 1 neutralization data. J Virol 70: 6235-43.

Pau CP, Kai M, Holloman-Candal DL, Luo CC, Kalish ML, Schochetman G, Byers B, George JR, WHO Network for HIV isolation and characterization 1994. Antigenic variation and serotyping of HIV type 1 from four World Health Organization-sponsored vaccine sites. AIDS Res Hum Retrov 10: 1369-1377.

Pilgrim AK, Pantaleo G, Cohen OJ, Fink LM, Zhou JY, Bolognesi DT, Fauci AS, Montefiori DC 1997. Neutralizing antibody responses to human immunodeficiency virus Type 1 in primary infection and longterm-nonprogressive infection. J Inf Dis 176: 924932.

Potts K, Kalish M, Lott T, Orloff G, Luo CC, Bernard MA, Alves C, Badaró R, Suleiman J, Ferreira O,
Schochetman G, Johnson W, Ou CY, Ho J 1993. Genetic heterogeneity of the V3 regio of the HIV-1 envelope glycoprotein in Brazil. AIDS 7: 1191-1197.

Simon F, Loussert-Ajaka I, Damond F, Saragosti S, Barin F, Brun-Vezinet F 1996. HIV type 1 diversity in northern Paris, France. AIDS Res Human Retrov 12: 1427-1433.

Stoneburner RL, Des Jarlais DC, Benezza D 1988. A larger spectrum of severe HIV-1 related disease in intravenous drug users in New York city. Science 242: 916-918.

Trkola A, Pomales AB, Yuan H, Korber B, Maddon PJ, Allaway GP, Katinger H, Barbas III CF, Burton DR, Ho DD, Moore JP 1995. Cross-clade neutralization of primary isolates of human immunodeficiency virus type 1 by human monoclonal antibodies and tetrameric CD4-IgG. J Virol 69: 6609-6617.

Wasi L, Herring B, Ratham S, Vanichseni S, Mastro TD, Young NL, Rübsamen-Waigsam H, von Briesen H, Kalish ML, Luo CC 1995. Determination of HIV-1 in intravenous drug injectors in Bangkok, Thailand, using peptide binding immunoassay and HMA: evidence of increasing infection with subtype E. AIDS 9: 843-849.

Weber J, Fenyö EM, Beddows S, Kaleebu P, Björndal A, WHO Network for HIV Isolation and Characterization 1996. Neutralization serotypes of HIV-1 field isolates are not predicted by genetic subtyping. $J$ Virol 70: 7827-7832. 